\author{
International Journal of Management Science and \\ Business Administration \\ Volume 6, Issue 6, September 2020, Pages 7-14 \\ DOI: $10.18775 /$ ijmsba.1849-5664-5419.2014.66.1001 \\ URL: http://dx.doi.org/10.18775/ijmsba.1849-5664-5419.2014.66.1001
}

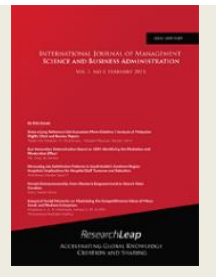

\title{
How Residents the Impacts of Tourism. The Case of the Historic Centre of Porto
}

\author{
${ }^{1}$ Maria Isabel Andres Marques, ${ }^{2}$ Maria Teresa Ribeiro Candeias, ${ }^{3}$ Carla Marisa Rebelo de Magalhaes \\ ${ }^{1}$ Univesdidade Lusofana CEPESE, Portugal \\ ${ }^{2,3}$ Univesdidade Lusofana, Portugal
}

\begin{abstract}
Considering the increase in the number of tourists and tourist flows in the city of Porto, especially in the parishes that make up the UNESCO World Heritage area and its surrounding protected areas, it is extremely important to analyse the perception that residents and professionals have about the dynamics that tourists bring to the city and the impacts of tourism in economic, socio-cultural and environmental terms. Thus, this study aims to assess the perception that residents of the city of Porto have on the impacts of tourist activity in the Historic Centre of Porto (CHP) and whether there is a relationship between the place of residence, the place of professional activity or study and the perception of the impacts of tourism in the Economic, Socio-cultural and Environmental aspects. For this purpose, a questionnaire survey was applied to a sample of 322 professionals and residents in the city of Porto. The results suggest that the respondents consider that tourism in Porto is growing harmoniously with the city and tourism activity has a direct influence on the overall improvement of the Centre of Porto. The aspects that is most relevant to the positive perception of tourism in the city is the socio-cultural component that shows that tourism development process in Porto is in an expansion phase.
\end{abstract}

Keywords: Environmental impact, Development, Economic impact, Socio-cultural impact, Tourism

\section{Introduction}

Tourism in the city of Porto has had a very expressive growth in recent years and the city is currently a stage of great changes. Recent studies indicate that in 2019 the city had 13 more hotel establishments than in the previous year, registering 107 in total. The Local Accommodation has registered the biggest increase, with a $120 \%$ increase from 2017 to 2018 and a 5\% increase in 2019 compared to 2018. In 2019 there were 8,000 Local Accommodation establishments in the city of Porto. In total, in 2019 the city had an increase of $5.2 \%$ in overnight stays compared to the previous year and has a total accommodation capacity of around 15,000 beds, according to data from INE. Taking into account the increase in the number of tourists in the city of Porto, especially in the parishes that make up the UNESCO World Heritage area and its surrounding protection areas, and knowing that this area of the city has a large number of resident and floating population (professionals who travel to the city of Porto every day to practice their profession) it is extremely important to analyse the perception that residents and professionals who inhabit the Historic Area of Porto have about the dynamics that tourists bring to the city and the tourism impacts in economic, socio-cultural and environmental terms.

\section{Literature Review}

Tourism is a sector of high importance for the development of historic cities whose heritage wealth is an important attraction for tourist activity strongly anchored in heritage and culture. The enhancement of the urban heritage and its touristification offer new opportunities for the physical and socioeconomic recovery of cities, also contributing to the increase in the number of tourists in urban centres (Vaquero and Hernández, 1998). This being a reality, it is also known that tourism is not an innocuous activity; its development impacts on destinations and the local population. The duality between preserving and sharing culture can create some constraints between resident communities and tourists (Besculides, Lee \& MacCormick, 2002) and the way residents and tourists interact is a theme that has been widely studied since the last decades. The evaluation that the receiving community makes of tourism depends, among other factors, on 
its tolerance to this activity, having repercussions on the way this community interacts with tourists and, therefore, on the concept of hospitality (Aires, Pequeno \& Fortes, 2010). This, being a social phenomenon, involves a set of structures and attitudes on the part of the local population and is based on a social relationship based on the principle of reciprocity permeated by greater or minor inequalities (Fortuna, 1999).

Hospitality depends on the quality of life of the hosts and this, in turn, is intrinsically related to the perceptions they have regarding the impacts of tourism activity (Aires, Pequeno \& Fortes, 2010). Authors such as Doxey (1975) and Cohen (1984) argue that the relationship between tourists and residents goes through several stages related to the stages of tourism development in destinations and that, if tourists are initially treated as part of traditional relationships, gradually, with its increase, resistance also arrives, based on the Butler Tourism Life Cycle (1980). It should be noted, however, that there are studies that contradict the trend that the perception is all the more negative the more mature the destination is (Besculides et al., 2009), verifying that the populations of mature destinations perceive the benefits in development tourism based on economic and cultural benefits (Dyer, Gursoy, Sharma \& Carter, 2007). The first studies on the perception of the local community on the impacts of tourism focused, essentially, on the economic impacts and only later did they begin to show the physical and social aspects, where variables of a qualitative order predominate (Hernández, 2000); in these, authors such as Mathieson and Wall (1982) and Pearce (1980) stand out, who typified the impacts of tourism as physical, economic and social. In the last two decades, studies on the perception of residents regarding the impacts of tourism have focused their analysis on the economic, socio-cultural and environmental aspects (Andereck, Valentine, Knopf \& Vogt, 2005; Andriotis, 2005). Multiple authors show the economic benefit as the main motivation of the receiving community in relation to tourism (Diedrich \& García-Buades, 2009; Gursoy, Jurowski, \& Uysal, 2002; Haralambopoulos \& Pizam, 1996; Krippendorf, 2001; Liu \& Var, 1986; Vargas- Sánchez, Plaza-Mejía \& Porras- Bueno, 2009), and which demonstrate that the economic impacts can be perceived as positive, resulting in job creation, the development of the local economy, the growth of investment, diversification economic activity, the increase in tax revenues, both at local and national levels, and in the increase in income and quality of life. However, these impacts can also be assessed negatively, resulting from the perception, by the residents, of an increase in the cost of living (increase in the price of goods and services) and an unequal distribution of benefits (Andereck \& Vogt, 2000; Andriotis, 2005; Liu \& Var, 1986; Haralambopoulos \& Pizam, 1996;). Andereck et al., 2005, concluded that, at first, the receiving populations give account of the economic impacts reflected in inflation, the increase in employment and income, but also in the increase in the cost of living. With regard socio-cultural impacts, studies highlight the importance given by communities to the resurgence of traditions and their cultural sharing (Weickert \& Kertstetter, 1996). These authors demonstrate that the tourist valuation of ancestral traditions supposes a renewal of the identity and pride that the communities have of their own culture, which positively influences the increase in the quality of life and image of the community, as well as their perception of the activity tourism (Besculides, Lee, \& McCormick, 2002; Gursoy \& Rutherford, 2004; Sirakaya, Teye \& Sönmez, 2002).

There are, however, several studies that indicate that residents have a negative view on the impacts of tourism in the socio-cultural sphere (Johnson, Snepenger \& Akis, 1994; Jurowski, Uysal \& Williams, 1997; Tosun, 2002), namely with regard to respect to the involvement of local populations in cultural activities (Dyer et al., 2007). Jurowski and Gursoy (2003) showed that communities further away from touristic activities consider that socio-cultural impacts are more positive. Regarding the environmental aspects, the positive impacts on the protection of wildlife and protected areas can be highlighted, but also the negative impacts in terms of increased air and water pollution, the destruction of natural life, vandalism and crime, and the excess waste caused by tourism (Andereck et al., 2005; Brunt \& Courtney, 1999). In the last decade, some studies have appeared that focus on the perceptions that local communities have about the impacts of tourism on their quality of life. In a 2011 study, \& Nyaupane's analysed the perception of local communities about the impacts of tourism on quality of life, considering some variables, such as well-being, lifestyle, pride and community awareness, natural and cultural preservation, economic importance, animation and substance abuse and crime. The results of the study show that there is a positive impact of tourism on the quality of life of communities when the local community has frequent contact with visitors and their relationship is intense and satisfactory and when they perceive that the development of tourism strengthens the economy and facilitates greater access to services (restaurants, shops, etc.) and attractions (festivals) (Andereck \& Nyaupane's, 2011). On the other hand, Carneiro and Eusébio (2015) conclude that, even when the interaction between residents and tourists is low and superficial, there are positive perceptions of the impacts of tourism in the different areas of their quality of life. It is important to highlight that local authorities must make efforts to include the local community in cultural animation activities, in order to keep it close to the spaces of socialization and cultural enjoyment, favouring the interaction between both communities (Vargaz-Sáchez et al., 2014). However, it is necessary to consider that there are constraints that influence the way the local community perceives the 
impacts of tourism. The literature has shown, above all, that residents agree to establish shares with tourists because these exchanges bring them more benefits than costs, in reference to the Social Exchenge Theory (Mazon, Huete \& Mantecon, 2009) and, thus, these have a such a positive reaction with tourists the greater their perception of the benefits of this sharing. Communities that obtain direct benefits from tourism and that are closer to home in relation to tourist attractions have a more positive perception of the impacts of this sector (Andereck et al., 2005; Andriotis \& Vaughan, 2003; Haralambopoulos \& Pizam, 1996; Jurowski \& Gursoy, 2003). The work developed by Davis, Allen and Cosenza (1988) presents the 4 types of residents studied by Krippendorf and concludes that type 1 includes people who have a direct relationship with tourists due to the profession they develop; type 2 are residents and business owners who do not have regular contact with tourists; the type no. 3 are residents who have direct and frequent contact with tourists, but whose income only benefits part of the tourists. The members of this group can feel the advantages, but they also have a critical view of the disadvantages. The type no. 4 includes places that do not have direct contact with tourists. This group has a variety of attitudes, ranging from approval to rejection, interest or indifference, this attitude being the most common. This study concludes that there is a correlation between the time that residents live in the place and their more pessimistic view on tourism. The study also shows that there is a relationship between the economic link to tourism and the positive perception of its impacts and between the distance from the residence to the tourist site. The greater the distance, the greater apathy for its impacts. In short, the perceptions about the impacts of the tourist activity are formed taking into account extrinsic aspects (moment of development of the tourist destination, type of tourists in the destination and seasonality of the destination) and extrinsic aspects (geographical proximity or contact with the tourist, characteristics sociodemographic, direct benefits of the tourist activity, degree of dependence, degree and type of participation of the resident in leisure activities, seniority of the residents in the place, which determines their connection to the terrain, knowledge of the individual and how this enables the levels of understanding tourism activity, political and demographic position, values and personality (Fredline \& Faulkner, 2000). According to several author the familiarity among residents and tourists benefits residents perception about tourism impacts (Harrill, 2004; Ko \& Stewart, 2002; Vargas-Sanchez, Porras-Bueno \& Plaza-Mejia, 2011). As tourism is one of the main drivers of development, urban, economic and social transformation of cities, and playing residents a crucial role in any tourist destination, it is therefore necessary to count on the participation and support of the local population in the models of tourism development, as essential elements for the success of destination management and planning (Pulido-Fernández, López-Sánchez \& Pulido-Fernández, 2013).

\section{Conceptual Framework}

According to the literature review, resident's perceptions and their overall evaluation of tourism impacts are determined by their socio-demographic characteristics. The theory suggests that if residents perceive that the positive impacts of tourism activity development are greater than the negative impacts, they can be more involved in the exchange process and support tourism development in their community (Andereck et al., 2005; Andriotis et al., 2003; Davis et al. 1988; Fredline \& Faulkner, 2000; Haralambopoulos et al., 1996; Harrill, 2004; Jurowski \& Gursoy, 2003; Ko \& Stewart, 2002; Mazon et al., 2009; Vargas-Sanchez et al., 2011). The hypotheses developed for this study are:

- H1 - Place of residence has influence on residents' perceptions of tourism impacts

- H1a: Place of residence has influence on residents' perceptions of tourism impacts on economic aspects.

- H1b: Place of residence has influence on residents' perceptions of tourism impacts on Socio-cultural aspects.

- H1c: Place of residence has influence on residents' perceptions of tourism impacts on environmental aspects.

- H2- Place of work/study has influence on residents' perceptions of tourism impacts

- H2a: Place of work/study has influence on residents' perceptions of tourism impacts on economic aspects.

- H2b: Place of work/study has influence on residents' perceptions of tourism impacts in socio- cultural aspects.

- H2c: Place of work/study has influence on residents' perceptions of tourism impacts on Environmental dimension.

\subsection{Survey Instrumental and Data Collection}

A survey questionnaire method was used for data collection. The questionnaire was based on previous studies on resident's perceptions of tourism development impacts in the community (Andereck et al., 2005; Andriotis, 2005). The result is a questionnaire divided in 2 parts. The first part consisted in 32 questions categorized and structured according to a five-point Likert Scale, ranging from "strongly disagree" option to "strongly agree" option. Those questions can be further divided into 3 blocks of statements regarding the following topics: 1) economic impacts of tourism development; 2) environmental impacts of tourism development and 3) socio-cultural impacts of tourism development. The second part collected resident's socio- demographic information: age, gender, education level, occupation and link to tourism industry. There were also considered geographic variables such as the length of time the respondent has been 
living/working in the area. A pre-test was conducted between in April and allowed to estimate the time needed to fill in the questionnaire.

The results suggested that 12 minutes were needed. The residents and workers were contacted and invited to fill in a questionnaire in May 2018. A previous analysis was conducted to identify questionnaires with missing data. To avoid biased results, questionnaires with missing data were eliminated.

\subsection{Statistical Procedures}

To reach our aim, several statistical procedures were carried out using SPSS (version 25). It was conducted a descriptive analysis to investigate resident's perceptions and to obtain a sample profile using socio-demographic information. To measure the internal consistency of the three factors alpha Cronbach's coefficient was computed for each factor. T-tests were used to identify differences between socio-demographic variables regarding the three scales measuring the perceived impacts of tourism development. T-tests were used to identify differences between socio-demographic variables regarding the three scales measuring the perceived impacts of tourism development when the independent variable is divided in two groups. When the independent variable is divided in two groups. When the independent variable was divided in three more groups ANOVA tests were applied.

\subsection{Study Location}

The surveys were distributed to the 7 parishes in the municipality of Porto. The parish of the city with the highest concentration of tourists is the Union of parishes of Cedofeita, Santo Ildefonso, Sé, Miragaia, São Nicolau and Vitória, where the historic downtown is located and the historic set classified by UNESCO as World Heritage.

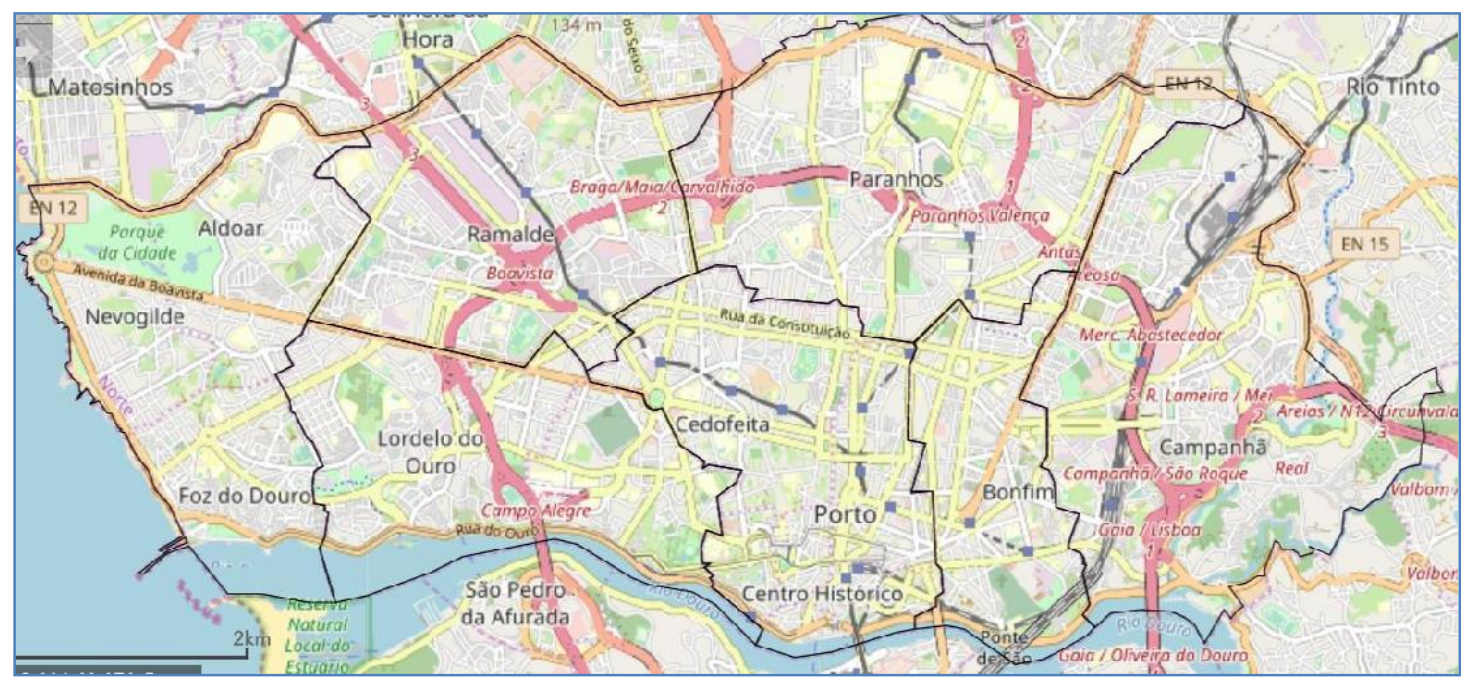

Figure 1: Porto Parishes

Source: INE

\section{Empirical Results}

\subsection{Profile of the Respondents}

Among the respondents, the majority are in the age group between 19 and 35 years $(41.6 \%)$, followed by the interval between 36 and 50 years $(23 \%)$ and, with a lesser representativeness, are those who are over 66 years old $(6.8 \%)$. Regarding gender, $51.2 \%$ are men and $48.4 \%$ are women. In the scope of the parish of residence, the respondents live, mostly (35.4\%), in parishes outside the municipality of Porto, followed by the parish of Campanhã, with $18.6 \%$ of representativeness. The one with the least expression is the parish of Ramalde. In the case of the work/study parish, most respondents came from Cedofeita, Santo Ildefonso, Sé, Miragaia, São Nicolau and Vitória, followed by the parish of Bonfim (with 14.9\%). The smallest parish is Ramalde (1.2\%). In the case of professional occupation, the highest percentage of responses concerns to professionals unrelated to the Tourism sector $(34.5 \%)$, followed by employees linked to commerce $(14.9 \%)$. Owners in the field of activities related to the hotel industry are those who were least represented in this study, with a percentage of only $1.6 \%$. Now moving to literary qualifications, most have secondary education 
(50.6\%), followed by graduates $(23.3 \%)$, those with basic education $(17.1 \%)$, those with a master's degree $(6.2 \%)$ and, finally, those with a $\mathrm{PhD}$ degree $(2.5 \%)$. As a last criterion to characterize the sample, we have the time spent in the workplace/study, with the greatest weight of responses being in the period of more than 10 years $(48.4 \%)$, followed by the period less than 1 year $(21.7 \%)$, with the least expressive period being between 6 and 9 years. In short, this study has a sample consisting mainly of the following characteristics: age group between 19 and 35 years old, mainly male, mostly resident in parishes outside the municipality of Porto and working/studying, in greater quantity, in Cedofeita, Santo Ildefonso, Sé, Miragaia, São Nicolau and Vitória, with a professional occupation, especially outside the Tourism sector, with literary qualifications at the level of secondary education and who has remained in the workplace/study for more than 10 years.

\subsection{Descriptive Analysis}

The most relevant aspects are the socio-cultural one, which is in line with the studies by Weickert and Kertstetter (1996), the demonstrate that the tourist valuation of cultural traditions can improve the perception of communities about the activity of Tourism

Table 1: Descriptive Statistics - aspects

\begin{tabular}{|c|c|c|c|c|c|}
\hline & N & Minimum & Maximum & $\begin{array}{c}\text { Average } \\
\text { Deviation } \\
\text { error }\end{array}$ \\
\hline Economic aspects & 322 & 1,73 & 5,00 & 3,4960 &, 54823 \\
\hline Socio-cultural aspects & 322 & 1,82 & 5,00 & 3,6823 &, 57318 \\
\hline Environmental aspects & 322 & 1,10 & 5,00 & 3,3365 &, 61574 \\
\hline Valid N (from list) & 322 & & & \\
\hline
\end{tabular}

In the context of the variables considered in the economic aspects, the ones that stood out most as being positive for the respondents' perception were the investment that Tourism attracts in the CHP and the increase in training at the level of Tourism professionals (both with a percentage of 4,30). Still close to these figures, we highlight the increase in jobs generated in the CHP (4.21), the increase in the income of economic agents (4.19) and the relevance that Tourism has for the development of the economy, in general, in CHP (4.18). What is assumed to have a less positive impact is the price of housing, followed by the cost of living, both in the CHP. These data are in line with the various authors who highlight the positive aspects of Tourism (Diedrich \& García-Buades, 2009; Gursoy et al., 2002; Haralambopoulos \& Pizam, 1996; Krippendorf, 2001; Liu \& Var, 1986), but also approach those who refer to their most negative aspects (Liu \& Var, 1986; Haralambopoulos \& Pizam, 1996; Andereck \& Vogt, 2000 and Andriotis, 2005). That is, if on the one hand Tourism can bring in revenue, on the other hand, it leads to an increase in the cost of living, which is also highlighted by Andereck et al. (2005).

Finally, in the case of the socio-cultural aspects, the variable that stood out most positively was the fact that Tourism allowed a revitalization of the CHP (4.01), followed by the increase and/ or improvement in public infrastructure $(3,82)$, security (3.78), the conservation of natural resources (3.74) and the improvement of accessibility and means of transport in the CHP (3.64). As less positive, the highlight is for traffic, pollution and dirt, in the CHP, which is in line with the studies by Andereck et al. (2005). Regarding the variables analyzed in terms of the environmental aspects, the highlight goes to the importance that Tourism can have in terms of a better understanding of the culture and society of other countries (4.29), following the dynamics that the tourist activity is creating at CHP, namely in terms of restaurants, nightlife, street entertainment, among others (4.16). The dynamism brought by tourists, the good integration between tourists and the people of Porto and the taste they have in welcoming people from other regions, also obtained expressive 
results, with average values in the order of 4 . The biggest concerns are the construction of hotels and other tourist facilities and the lack of characterization of the CHP's identity, as a consequence of tourism activity. Positive and negative aspects of tourism, at the environmental level, were considered by Andereck et al. (2005) and Brunt and Courtney, (1999).

\subsection{Reliability of the Scales}

A confirmatory factor analysis showed the unidimensionality of the scale, consequently the values of the 11 items were summed and averaged to create economic impact construct (Cronbach alpha $=.75$ ). Socio-cultural aspects were measured using a scale of 11 items. The confirmatory factor analysis reveals unidimensionality for the construct and the 11 items were also summed and averaged (Cronbach alpha $=.81$ ). Environmental impact was measured using a scale of 10 items. The confirmatory factor analysis reveals unidimensionality for the construct and the 10 items were also summed and averaged (Cronbach alpha $=.78)$.

\subsection{Anova Analysis}

A simple ANOVA was conducted using the statistical package SPSS. The results showed that the place of residence has influence on residents' perceptions of tourism impacts on economy $(p<.05)$. Residents considerer that tourism has a positive impact on local economy (mean=3.50). This finding is in line with the results of the study Andereck et al., 2005; Andriotis \& Vaughan, 2003; Davis et al., 1988; Diedrich \& García-Buades, 2009; Gursoy et al., 2002; Krippendorf, 2001; Liu \& Var, 1986; Haralambopoulos \& Pizam, 1996; Jurowski \& Gursoy (2003). According to the results parishes with higher levels of touristic activities consider that the impact is less positive like Bonfim (mean $=3.36$ ), Cedofeita, Santo Ildefonso, Sé, Miragaia, São Nicolau e Vitória (mean = 3.31), Lordelo do Ouro e Massarelos $($ mean $=3.15)$ than those that are further away such as Aldoar, Nevogilde e Foz do Douro (mean = 3.8), Ramalde (mean= 3.8), Paranhos $($ mean $=3.71)$ and Campanhã (mean $=3.56)$. The findings indicated that the place of residence has no statistically significant influence on residents' perceptions of tourism impacts on socio-cultural aspects ( $p>.05)$. This evidence is no similar to the study by Davis et al., (1988). Results have demonstrated that place of residence has statistically significant influence on residents' perceptions on environmental effects of tourism $(p=0.000)$. This finding is similar to the result of the study (Fredline \& Faulkner, 2000; Davis et al., 1988; Harrill, 2004; Ko \& Stewart, 2002; Vargas-Sanchez, PorrasBueno, \& Plaza-Mejia, 2011). The results suggest that residents do not have a very expressive positive position about the perception of tourism impact in terms of environmental aspects (mean=3.34). Although, the results shows that parishes were tourism activity is greater consider that the impact is less positive like Cedofeita, Santo Ildefonso, Sé, Miragaia, São Nicolau e Vitória (mean = 3.03), Lordelo do Ouro e Massarelos (mean = 3.05) than those that are further away like Aldoar, Nevogilde e Foz do Douro (mean = 3.75). Regarding place of work/study, it has influence on residents' perceptions of tourism impacts on local economy $(\mathrm{p}<.05)$. The result showed that workers and students considerer that tourism has a positive impact on economic aspects (mean=3.50). This finding is in line with the results of some studies (Andereck et al., 2005; Andriotis \& Vaughan, 2003; Davis et al., 1988; Diedrich \& García-Buades, 2009; Gursoy et al., 2002; Haralambopoulos \& Pizam, 1996; Jurowski \& Gursoy, 2003; Krippendorf, 2001, Liu \& Var, 1986). According to the results parishes were tourism activity is greater consider that the impact is less positive (Cedofeita, Santo Ildefonso, Sé, Miragaia, São Nicolau e Vitória [3,4]; Lordelo do Ouro e Massarelos [3,25] than those that are further away like Aldoar,

Nevogilde e Foz do Douro (mean = 3.85) and Campanhã (mean = 3.62). Regarding place of work/study, it has influence on residents' perceptions of tourism impacts on socio-cultural aspects $(\mathrm{p}<.05)$. The results suggest that workers and students consider positive the impact of tourism in terms of socio-cultural aspects (mean=3.68). This finding is in line with the results of Andereck and Nyaupane's (2011), Fredline and Faulkner (2000), Davis et al., (1988) and Jurowski and Gursoy (2003). The results showed that workers and students that develop their activity in parishes were tourism activity is less expressive (parishes further away from the historic center) evaluate more positively the impact of tourism in this aspects: Aldoar, Nevogilde e Foz do Douro (mean = 3.97), Campanhã (mean = 3.86), Bonfim (mean = 3.73), Paranhos $($ mean $=3.67)$, Ramalde $($ mean $=3.55)$, Cedofeita, Santo Ildefonso, Sé, Miragaia, São Nicolau e Vitória $($ mean $=3.59)$ and Lordelo do Ouro e Massarelos (mean = 3.43). Finally, place of work/study has influence on residents' perceptions of tourism impacts on environmental aspects $(\mathrm{p}<.05)$. Workers and students showed a positive perception, although slight, bout the impact of tourism in environmental aspects (mean =3.34). This finding is in line with the results of the studies: Davis et al. (1988), Fredline and Faulkner (2000), Harrill (2004), Ko and Stewart (2002) and Vargas-Sanchez, Porras-Bueno, and Plaza-Mejia (2011). The results suggest that workers and students who develop their activity in parishes were tourism activity is greater Cedofeita, Santo Ildefonso, Sé, Miragaia, São Nicolau e Vitória $($ mean $=3.21)$ 
and Lordelo do Ouro e Massarelos (mean = 3,22) consider the impact less positive, unlike workers and students from parishes that are further away consider that the impact is more positive as Aldoar, Nevogilde e Foz do Douro (mean = 3,90). The above finding evidence the following results.

- H1 - Place of residence has influence on residents' perceptions of tourism impacts

- H1a: Place of residence has influence on residents' perceptions of tourism impacts on economic aspects - Accepted

- H1b: Place of residence has influence on residents' perceptions of tourism impacts on Socio-cultural aspects- Rejected

- H1c: Place of residence has influence on residents' perceptions of tourism impacts on environmental aspects- Accepted

- H2- Place of work/study has influence on residents' perceptions of tourism impacts

- H2a: Place of work/study has influence on residents' perceptions of tourism impacts on economic aspects - Accepted

- H2b: Place of work/study has influence on residents' perceptions of tourism impacts in socio- cultural aspects Accepted

- H2c: Place of work/study has influence on residents' perceptions of tourism impacts on Environmental dimension Accepted

\section{Conclusion}

From this study it can be concluded that residents, professionals and students from the city of Porto have a positive perception of tourism in the city. Of the aspects studied, we can highlight that it is socio-cultural that has the most expressive value. It is also possible to verify that the place of residence has influence on residents 'perceptions of tourism impacts on economic and environmental aspects, but there is no correlation between the place of residence and the sociocultural aspects.

Regarding the place of work/study, it influences the perception of economic, socio-cultural and environmental impacts. The results suggest that the respondents consider that tourism in Porto is growing harmoniously with the city and tourism activity has a direct influence on the overall improvement of Porto Downtown. In general residents showed a positive perception of tourism impacts in all the aspects: economic, socio-cultural and environmental, although it is perceived that the respondents have a more positive perception the greater the distance from their home and workplace/study to the places of greatest tourist pressure in the city. This evidence suggests that tourism development process in Porto is in an expansion phase and that if residents have an important role in any tourist destination, it is necessary to count on the participation and support of the local population in the models of tourism development, as essential elements for the success of destination management and planning.

\section{References}

- Andereck, K., C. Vogt. (2000). The Realtionship between Resident's Attitudes Toward Tourism and Tourism and Tourism Development Options, Journal of Travel Research, 39 (1), 27-36. CrossRef

- Andereck, K. Valentine K., Knopf R., Vogt Chr. (2005). Resident's perceptions of community tourism impacts. Annals of Tourism Research, Vol 32, n 4, pp. 1056-1076. CrossRef

- Andereck, K. L., Nyaupane, G. P. (2011). Exploring the nature of tourism and quality of life perceptions among residents. Journal of Travel research, 50(3), 248-260. $\underline{\text { CrossRef }}$

- Andriotis, K. (2005). Community groups' perceptions of and preferences for tourism development: Evidence from Crete. Journal of Hospitality \& Tourism Research, 29(1), 67-90. CrossRef

- Aires, J. D. M.; Pequeno, E. A., Fortes, L. (2010). A relação entre turistas estrangeiros e residentes: o caso de Ponta Negra - Natal/RN. Revista Hospitalidade. São Paulo, 7(2), 38- 51.

- Carneiro, M. J., Eusébio, C. (2015). Host-tourist interaction and impact of tourism on residents' Quality of Life. Tourism \& Management Studies, 11(1), 25-34.

- Besculides, A., Lee M. e MacCormick, P.J. (2002). Resident's Perceptions of the Cultural Benefits of Tourism, Annals of Tourism Research, 29(2), 303-319. CrossRef

- Brunt, P., Courtney, P. (1999). La percepción de los impactos socio-culturales del turismo por la población residente. Annals of tourism research en español, ISSN 1575-443X, Vol. 1 (2), (1999), 215-239 
- Cohen, E. (1984). The sociology of tourism: approaches, issues, and findings. Annual review of sociology, 10(1), 373-392.

- Diedrich, A., García-Buades, E. (2009). Local perceptions of tourism as indicators of destination decline. Tourism Management, 30(4), 512-521. CrossRef

- Doxey, G. V. (1975). A causation theory of visitor-resident irritants: Methodology and research inferences. In Travel and tourism research associations sixth annual conference proceedings. 195-98.

- Dyer, P., Gursoy, D., Sharma, B., Carter, J. (2007). Structural modeling of resident perceptions of tourism and associated development on the Sunshine Coast, Australia. Tourism management, 28(2), 409-422. CrossRef

- Fortuna, C. (1999). Identidades, Percursos, Paisagens Culturais. Oeiras: Celta Editora

- Fredline, Elizabeth, \& Bill Faulkner. (2000). Host community reactions: A cluster analysis.

- Annals of tourism research 27(3),763-784. CrossRef

- Gursoy, D., Jurowski, C., Uysal, M. (2002). Resident attitudes: A structural modeling approach. Annals of tourism research, 29(1), 79-105. CrossRef

- Gursoy, D., \& Rutherford, D. G. (2004). Host attitudes toward tourism: An improved structural model. Annals of tourism Research, 31(3), 495-516. CrossRef

- Haralambopoulos, N., Pizam, A. (1996). Perceived impacts of tourism: The case of Samos. CrossRef

- Annals of tourism Research, 23(3), 503-526.

- Harrill, R. (2004). Residents' attitudes toward tourism development: A literature review with implications for tourism planning. Journal of planning literature, 18(3), 251-266. CrossRef

- Hernández, M. G. (2000). Turismo y medio ambiente en ciudades históricas. De la capacidad de acogida turística a la gestión de los flujos de visitantes. Anales de geografía de la Universidad Complutense, 2000 (20), 131-148.

- Johnson, J. D., Snepenger, D. J., Akis, S. (1994). Residents' perceptions of tourism development. Annals of tourism research, 21(3), 629-642. CrossRef

- Jurowski, C., Uysal, M., Williams, D. R. (1997). A theoretical analysis of host community resident reactions to tourism. Journal of travel research, 36(2), 3-11. CrossRef

- Jurowski, C., \& Gursoy, D. (2004). Distance Effects on Resident's Attitudes Toward Tourism. Annals of tourism research, 31(2), 296-312. CrossRef

- Ko, D. W., Stewart, W. P. (2002). A structural equation model of residents' attitudes for tourism development. Tourism management, 23(5), 521-530. CrossRef

- Krippendorf, J. (2001). Sociologia do turismo: para uma nova compreensão do lazer e das viagens. [trad. Contexto Traduções]. 2. ed. São Paulo: Aleph, 2001. Titulo original: Die Ferienmenschen.

- Liu, J. C., Var, T. (1986). Resident attitudes toward tourism impacts in Hawaii. Annals of tourism research, 13(2), 193-214. CrossRef

- Mathieson, A., Wall, G. (1982). Tourism, economic, physical and social impacts. Longman.

- Mazon, T., Huete, R., Mantecon, A. (2009). Tourism dependence and host community perceptions: Notes on the social exchange theory. Encontros Científicos [online]. 2009, 5, 25-36. ISSN 1646-2408.

- Pulido-Fernández M. de la C., López-Sánchez, Y., Pulido-Fernández, J. I.o (2013) Methodological Proposal for the Incorporation of Governance as a Key Factor for Sustainable Tourism Management: The Case of Spain, International Journal of Humanities and Social 3(15).

- Sirakaya, E., Teye, V., Sönmez, S. (2002). Understanding residents' support for tourism development in the central region of Ghana. Journal of travel research, 41(1), 57-67. CrossRef

- Tosun, C. (2002). Host perceptions of impacts: A comparative tourism study. Annals of tourism research, 29(1), 231-253. CrossRef

- Vaquero, M. de la C., Hernández, M. G., (1998), Ciudades Históricas: património cultural y recurso turístico. Ería Revista de Geogafía Universidad Complutense de Madrid, 47, 249-266.

- Vargas-Sanchez, A., Porras-Bueno, N., de los Ángeles Plaza-Mejía, M. (2011). Explaining residents' attitudes to tourism: Is a universal model possible?. Annals of tourism research, 38(2), 460-480. CrossRef 